\title{
Safety and Effectiveness of Trichlorfon in Prevention of Lernaeosis and Its Comparison with Plant Extracts in Lernaeosis Control
}

\author{
Manal A. A. Essa (D), Fatma M.M. Korni iD
}

Cite this article as: Essa, M.A.A., Korni, F.M.M. (2018). Safety and effectiveness of trichlorfon in prevention of lernaeosis and its comparison with plant extracts in lernaeosis control. Aquatic Sciences and Engineering, 33(2): 32-38.

\begin{abstract}
This study was carried out to evaluate the safety and effectiveness of trichlorfon in prevention of lernaeosis among hatchery-reared cyprinids. Also, it compared with plant extracts (carvacrol and cymene mixture and thyme) in lernaeosis control. At the Abo-Saleh fish hatchery in BeniSuef, Egypt, the trichlorfon bioconcentrations of cyprinids fries and fingerlings, as well as soil, water and plant samples were examined for 2 years. Trichlorfon was detected in fingerlings, water and plant samples, except soil sampled $1 \mathrm{hr}$ after trichlorfon was applied to the fish pond. The highest concentration of trichlorfon was in fish, followed by water and plant samples. No trichlorfon was detected in fingerlings, water, plant and soil sampled after 5 days and 5 months. Fingerlings and brooders of cyprinids were examined in situ for clinical abnormalities and prevalence of lernaeosis. In addition, the intensity of the lernaea infestation was determined. Macroscopic Lernaea cyprinacea females were seen attached to the skin and fins associated with swollen hyperemic nodules and open wounds. Lernaeosis appeared sporadically during examination seasons with a high intensity. Under experimental condition, trichlorfon succeeded in controlling lernaeosis among Ctenophyrngedon idella fingerlings, as it eliminated $100 \%$ of Lernaea cyprinacea in comparison with $74.28 \%$ and $50.2 \%$ in carvacrol and cymene mixture and thyme treated fish respectively.
\end{abstract}

Keywords: Trichlorfon, cyprinids, lernaeosis, carvacrol, cymene, thyme

Department of Fish Diseases and Management, Faculty of Veterinary Medicine, Beni-Suef University, Egypt

Submitted:

10.10.2017

Accepted:

07.02.2018

Available Online Date:

21.02.2018

Correspondence:

Fatma M.M. Korni

E-mail:

naglaamostafa1@yahoo.com

(C) Copyright 2018 by Aquatic

Sciences and Engineering

Available online at

dergipark.gov.tr/tjas

\section{INTRODUCTION}

Hatcheries are considered very important aspect in the aquaculture industry through supplying larval and juveniles and genetic improvement by selective breeding programs which aim to improve production characteristics such as increase growth rate, survival, fecundity and diseases resistance (https://en.wikipedia.org/ wiki/Fish_hatchery).

Cyprinidae is the largest family of freshwater fishes in the world (Nelson, 1994) and including the main species is reared in the hatcheries. Cyprinids have important ecological, commercial, nutritional and scientific values. Grass carp (Ctenopharyngodon idella, C. idella), silver carp (Hypophthalmichthys molitrix, H. molitrix) and common carp (Cyprinus carpio, C. carpio) are economically important and fast growing food fish (Rashid et al., 2014). In addition, C. idella is used as biological control for aquatic weeds (Nelson, 2016).

The causative agent of lernaeosis, Lernaea cyprinacea (L. cyprinacea), is considered harmful ectoparasite to cyprinids wherever they cultured because of the damage and the economic losses (Noor El-Deen et al., 2013).

Lernaeosis is a dangerous disease affecting cyprinids in different parts of the world and it is endemic in Egyptian hatcheries since 1980 ( $\mathrm{Fa}$ sial et al., 1988). Several studies on the prevalence of lernaeosis among hatchery reared cyprinids in Egypt were carried out (Abd El-Galil, 2002; Saleh et al., 2009; Abd El-Galil et al., 2012; Korni, 2014). 
Knowledge of the lernaeosis prevalence gives an idea about the efficacy of the prevention and control programs. The current measures in Egyptian hatcheries for prevention and control of lernaeosis rely on the use of organophosphate insecticides mainly trichlorfon. Trichlorfon is a selective organophosphate insecticide used in agriculture and veterinary to control a variety of arthropod pests through inhibition of acetilcolinesterase (Lopes et al., 2006). In Brazil, trichlorfon has not a restricted use and its products are marketed for homeowner use (EPA, 2001) and in fish cultures to control lernaeosis and argulosis (Lopes et al., 2006). Also, it is used in Asia in the production of several fish species and in Europe and Chile to control epizooties in salmon and trout cultures (Lopes et al., 2006). Oppositely, in United States (USA), trichlorfon is currently registered for non-agricultural uses such as commercial animal kennels, ornamental plants and baitfish ponds due to its toxicity to fish stocks and farm workers as well as its side effects on the environment causing water and soil pollution (Lopes et al., 2006).

Several trials were carried out in many parts of the world to find effective and safe methods for getting rid of lernaeosis. These trials included mechanical (Faisal et al., 1988) biological (Tamuli and Shanbhogue, 1995; Xinhua, 1999) and chemical alternatives that less toxic than organophosphate for lernaeosis eradication (Tamuli and Shanbhogue, 1996; Zaki, 1999; Abd El-Moula, 2001; Abd El-Galil, 2004; Noga, 2010). Recently, studies have been used plant extracts as castor oil, resin extract and thyme extract (Rosa, 2003; Sataporn, 2004; Korni, 2014) for prevention and control of lernaeosis.

Depending on the aforementioned data, this study was planned to evaluate the safety and effectiveness of trichlorfon under field condition in prevention of lernaeosis among hatchery reared cyprinids. Also, it was compared with plant extracts in lernaeosis control among $C$. idella.

\section{MATERIAL AND METHOD}

\section{Trichlorfon Insecticide}

Trichlorfon $80 \%$ of United Company for chemicals and medical preparations (UCCMA, Egypt) is used.

\section{Plant Extracts}

Thyme, carvacrol and cymene (Sigma-Aldrich Chemie GmbH, Steinheim, Germany) are used.

\section{Site of Field Study (Abo-Saleh fish hatchery)}

Abo-Saleh fish hatchery is located in Beni-Suef, Egypt. It supplies north Upper Egypt especially Beni-Suef and El-Fayum areas with fries and fingerling of cyprinids (General Authority for Fisheries Development of the Ministry of Agriculture, http://www. gafrd.org). C. idella, $H$. molitrix and $C$. carpio are reared in that hatchery, but the main artificially breeded species is $C$. idella as it provides promising alternatives to traditional methods of weed control in Egypt. In Abo-Saleh fish hatchery, as most of Egyptian hatcheries, trichlorfon is used for lernaeosis prevention through its addition to the incubated ponds $\left(1 / 3 \mathrm{gm} / \mathrm{m}^{3}\right) 72 \mathrm{hrs}$ before fries stocking. There is no water changing for 5 months until the fries become fingerlings, only the evaporated water is compensated.

\section{Determination of Trichlorfon Bioconcentration}

Two trials were carried out for determination of trichlorfon bioconcentration in hatchery reared fries and fingerlings and their environments (water, plant and soil) in the field. In first one, after 5 days from spreading of field dose (1/3 gm per $\left.\mathrm{m}^{3}\right)$ of commercial trichlorfon in one earthen pond (16 curate and $1 \mathrm{~m}$ water depth) having polycultured C. idella, H. molitrix and C. carpio fries $(0.05-0.1 \mathrm{gm}, 0.5-1 \mathrm{~cm})$, water, plant and soil samples were collected. Also, after 5 months, samples of fish fingerlings (80-150 gm, 10-18 cm), water, plant and soil were taken. In second trial, after $1 \mathrm{~h}, 5$ days and 5 months post spreading of the same dose of trichlorfon in similar pond having polycultured $C$. idella, $H$. molitrix and $C$. carpio fingerlings (60-120 gm, 15-18 cm), fish, water, plant and soil samples were collected.

At each sampling time, $1 \mathrm{~kg}$ of apparently healthy fingerlings from each fish species, 3 liters water, $1 \mathrm{~kg}$ of green plant and $1 \mathrm{~kg}$ of soil were taken (Devine 1973). Also, water temperature and pH were measured using water thermometer (UK) and $\mathrm{pH}$ indicator paper (USA) respectively. Each water sample was taken at $15 \mathrm{~cm}$ depth of water surface and at three different locations (1 liter per location). The first at water entry, the second at middle pond and the third at water exit (Lopes et al., 2006).

Each water sample was kept in dark glass bottle, while, each fish, plant and soil sample was kept in separate plastic bag, labeled and frozen at $-20 \pm 2{ }^{\circ} \mathrm{C}$ till analysis (Lopes et al., 2006). All samples were analyzed for trichlorfon qualitatively and quantatively in the Central laboratory of pesticides (Dokki, Egypt) by using the Agilent Gas Chromatography (GC, Model 6890) and according to the method described by Hem (2010).

\section{Clinical Examination of Hatchery Reared Cyprinids for Lernaeosis} A total of 12600 fingerlings and 3150 brooders of cultured cyprinids were randomly collected alive from Abo-Saleh fish hatchery, Beni-Suef, Egypt. Fish samples were randomly collected 3 times per month, from April to October i.e. lernaeosis season for two successive years (2015 and 2016). Each time, 100 fingerlings and 25 brooders were visually examined in situ for lernaeosis according to Noga (2010). The examined C. idella, H. molitrix and C. carpio fingerlings and brooders were $3-150 \mathrm{gm}(5-19 \mathrm{~cm}), 2.250-6 \mathrm{~kg}(25-$ $32 \mathrm{~cm}), 3.5-130 \mathrm{gm}(6-20 \mathrm{~cm}), 3-5 \mathrm{~kg}(27-35 \mathrm{~cm}), 3-160 \mathrm{gm}(4-19 \mathrm{~cm})$ and $3-7.5 \mathrm{~kg}(25-39 \mathrm{~cm})$ respectively. Clinical abnormalities, prevalence of the disease and intensity of the infestation were recorded.

\section{Water Quality Determination}

During collection of fish samples for lernaeosis examination, temperature and $\mathrm{pH}$ of pond water were measured using water thermometer (UK) and $\mathrm{pH}$ indicator paper (USA).

\section{Parasitological Examination}

Learnaea suspected parasite was collected from naturally infested fish and fixed in glycerin-alcohol 70\%. Permanent mounts were prepared according to Becky (2004) and identification of the suspected parasites was done according to Woo (1995).

\section{Preparation of Plant Extracts Water-Soluble Form}

Each $100 \mathrm{ul}$ of carvacrol and cymene was dissolved in $5 \mathrm{~mL}$ of Dimethyl sulfoxide (DMSO) and mixed together for using as one solution. Similarly, each $100 \mathrm{ul}$ of thyme was prepared (Bernd et al., 2012). 


\section{Determination of LC50 of Trichlorfon, Carvacrol and Cymene Mixture and Thyme among $C$. idella Fingerlings}

A total of 300 apparently healthy $C$. idella fingerlings with body weight ranged from $50-85 \mathrm{gm}$ and total length $(15-19 \mathrm{~cm})$ were brought back to the wet lab. of fish diseases and management department, Faculty of Veterinary Medicine, Beni-Suef University, Egypt. They were acclimatized for 14 days in 3 fiberglass tanks (400 L water for each) as 100 fish/tank. After that, they were redistributed into 30 glass aquaria of $70 \times 25 \times 40 \mathrm{~cm}$, supplied with chlorine-free tap water (water temperature $25 \pm 2^{\circ} \mathrm{C}, \mathrm{pH}=7 \pm 0.3$ ) and continuous aeration in a rate of 10 fish/aquaria. First ten fish groups received zero (control), 100, 200, 300, 400, 500, 600, 700, 800 and $900 \mathrm{ul} / \mathrm{l}$ of carvacrol and cymene mixture. Second ten fish groups received similar concentrations of thyme. Third ten fish groups received trichlorfon concentration of zero (control), $10,20,30,40,50,60,70,80$ and $90 \mathrm{mg} / \mathrm{l}$. The $\mathrm{LC}_{50}$ of each product was calculated according to Behrens and Kerber (1953) using the following formula:

24 hours $\mathrm{LC}_{50}=$ largest dose which killed all fish $-\Sigma(\mathrm{A} \times \mathrm{B}) / \mathrm{n}$

$A=$ Mean of dead fish between 2 successive dose

$B=$ Dose difference between 2 successive doses

$\Sigma(A \times B)=$ summation of $(A x B) n=$ No. of fish/group

Lernaeosis Control among $C$. idella Fingerlings by Trichlorfon, Carvacrol and Cymene Mixture and Thyme

A total of forty eight lernaeosis naturally infested fish and equal number of apparently healthy ones with body weight ranged from 55-65 gm and total length $14-16 \mathrm{~cm}$ were brought back to the wet lab. of Fish Diseases and Management department, Faculty of Veterinary Medicine, Beni-Suef University, Egypt. They were distributed into 8 groups, each one put in glass aquaria of $70 \times 25 \times 40 \mathrm{~cm}$. First 3 groups of lernaeosis infested fish were treated with $0.33 \mathrm{mg} / \mathrm{l}$ of trichlorfon (field dose), $200 \mathrm{ul} / \mathrm{l}$ of carvacrol and cymene mixture (Korni, 2014), $200 \mathrm{ul} / \mathrm{l}$ of thyme respectively. Fourth group of infested fish was left without treatment as positive control. Fifth, sixth and seventh groups of apparently healthy fish were treated with similar doses of trichlorfon, carvacrol and cymene mixture and thyme, while eighth group of healthy fish received no treatment as negative control. All groups except controls were exposed to the various treatments for $48 \mathrm{hrs}$ water bath. After bath duration, the fish was transported to clean water. The lernaea was counted just before application of treatment products and at $7^{\text {th }}$ day after bath duration. The treatment products were applied in two regime, each regime included application of the products once weekly for 2 times ( 2 weeks).

\section{Statistical Analysis}

Statistical analysis was performed using the GRAPHPAD INSTAT (software, Philadelphia, USA). Data were expressed as means \pm stander error (SE)

\section{Ethics}

The present study was approved by the BSU-IACUC (Beni-Suef Institutional Animal Care and Use Committee).

\section{RESULT AND DISCUSSION}

\section{Trichlorfon Bioconcentration}

In first trial, trichlorfon was not detected in water, soil and plant samples post 5 days from its application in the pond. In second one, trichlorfon was detected in water, plant and fish fingerlings except soil sampled after $1 \mathrm{hr}$ from its application (Figure 1) and its concentrations were 0.039 ppm, 0.004 ppm and 1.076 ppm respectively. On contrarily, it was not detected after 5 days and 5 months in all samples. In first trail, the temperatures and $\mathrm{pH}$ at 5 days and 5 months post trichlorfon application were $22^{\circ} \mathrm{C}, 27^{\circ} \mathrm{C}$, 7 and 8 respectively. In the second trial, the temperature and $\mathrm{pH}$ at $1 \mathrm{~h}, 5$ days and 5 months post trichlorfon application were $23^{\circ} \mathrm{C}, 21,25^{\circ} \mathrm{C}, 7,8$ and 7 respectively.

\section{Clinical Abnormalities of Lernaeosis Infested Cyprinids}

The infested fingerlings and brooders of cyprinids showed the attachment of worm- like parasite that was focally distributed along both fish sides. Also, there were swollen hyperemic nodules and open wounds at the site of attachment (Figure 2). Based on the morphological characters and the structure of two pairs of horn-shaped cephalic chitinious appendages, the parasite was identified as L. cyprinacea.

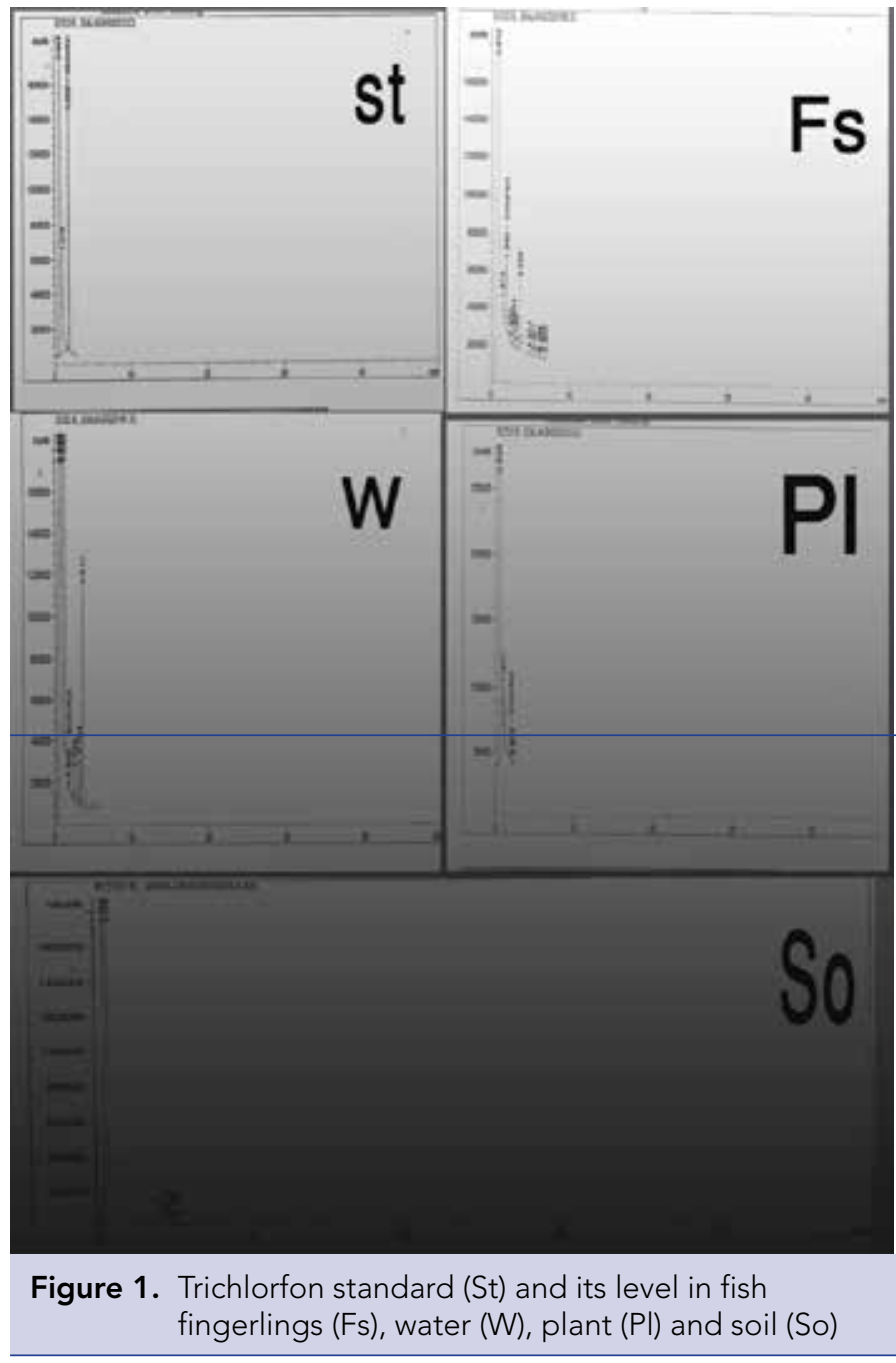




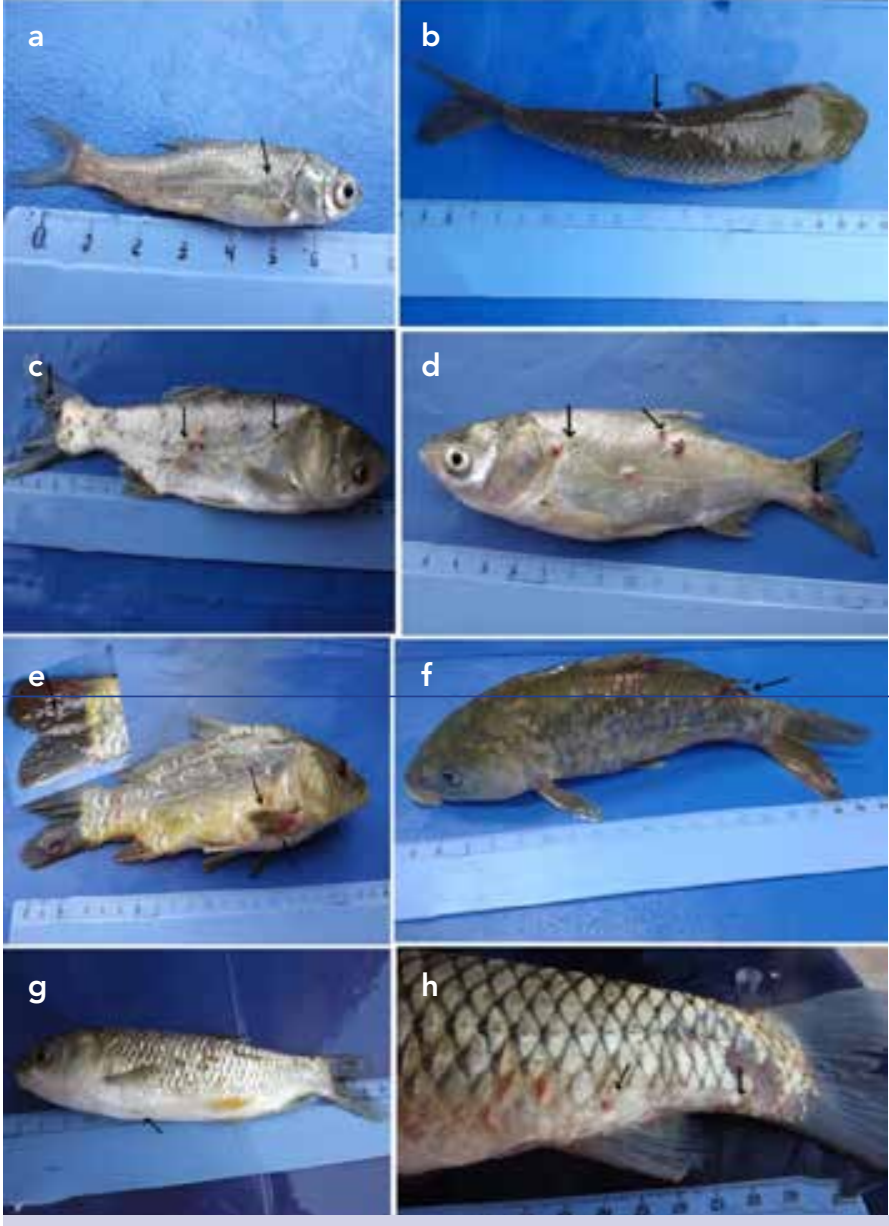

Figure 2. A-H. Clinical abnormalities of lernaeosis naturally affected cyprinids fingerlings and brooders. The L. cyprinacea was attached to pectoral (a) and dorsal fins (b) of $C$. idella fingerlings. L. cyprinacea penetrated the body sides of $\mathrm{H}$. molitrix fingerlings showing their egg sacs with hyperemic nodules and open wounds (c, d). Macroscopic reddening and hemorrhagic nodules around the attachment point of L. cyprinacea around pectoral fin, tail fin and dorsal fin of $C$. carpio fingerlings (e, f). C. idella brooders showed the attachment of $L$. cyprinacea at the ventral side of the body $(\mathrm{g})$ and caudal peduncle $(\mathrm{h})$

\section{Lernaeosis Prevalence and Intensity}

The prevalence among fingerlings and brooders of cyprinids varied according to species and seasons. In the first season of study (April to October, 2015), the prevalence of lernaeosis among fingerlings of $\mathrm{C}$. idella, $\mathrm{H}$. molitrix and $\mathrm{C}$. carpio was $0.047 \%, 0 \%$ and $0 \%$ respectively, while, its prevalence among $\mathrm{C}$. idella, $H$. molitrix and $C$. carpio brooders were $1.71 \%, 0 \%$ and $0 \%$ respectively. In the second season of study (April to October, 2016), the prevalence of lernaeosis among fingerlings of $\mathrm{C}$. idella, $\mathrm{H}$. molitrix and $\mathrm{C}$. carpio was $3.33 \%, 1.57 \%$ and $1.42 \%$ respectively, while, its prevalence among $C$. idella, $H$. molitrix and $C$. carpio brooders were $0.19 \%, 0 \%$ and $0 \%$ respectively. The infestation intensity in the infested fingerlings of $\mathrm{C}$. idella, $\mathrm{H}$. molitrix and $\mathrm{C}$. carpio were 1-15, 1-19 and 1-13 parasite/fish respectively.
Table 1. The temperature and $\mathrm{pH}$ of pond water during fish sampling for lernaeosis examination (2015 \& 2016)

\begin{tabular}{lcccc}
\hline \multirow{2}{*}{ Year } & \multicolumn{2}{c}{2015} & \multicolumn{2}{c}{2016} \\
\cline { 2 - 5 } Month & $\begin{array}{c}\text { Temperature } \\
\left({ }^{\circ} \mathrm{C}\right)\end{array}$ & $\mathrm{pH}$ & $\begin{array}{c}\text { Temperature } \\
\left({ }^{\circ} \mathrm{C}\right)\end{array}$ & $\mathrm{pH}$ \\
\hline April & $21.66 \pm 0.3$ & $6.3 \pm 0.3$ & $22.57 \pm 0.5$ & $6.6 \pm 0.6$ \\
May & $29 \pm 0.5$ & $6.3 \pm 0.3$ & $28 \pm 1.1$ & $6.3 \pm 0.3$ \\
June & $29 \pm 0.5$ & $7.6 \pm 0.3$ & $29 \pm 0.5$ & $7.6 \pm 0.3$ \\
July & $32 \pm 0.5$ & $7 \pm 0.5$ & $29.6 \pm 0.3$ & $7 \pm 0.5$ \\
August & $29 \pm 0.3$ & $7 \pm 0.5$ & $27 \pm 1.4$ & $7.3 \pm 0.3$ \\
September & $29 \pm 0.5$ & $7.3 \pm 0.3$ & $23.3 \pm 0.8$ & $8.1 \pm 0.1$ \\
October & $27 \pm 0.3$ & $7.3 \pm 0.3$ & $23.66 \pm 0.8$ & $7.6 \pm 0.3$ \\
\hline
\end{tabular}

Table 2. 24 hours median lethal concentration of trichlorfon in C. idella fingerlings

\begin{tabular}{lcccccc}
\hline $\begin{array}{c}\text { Fish group } \\
\text { Trichlorfon }\end{array}$ & $\begin{array}{c}\text { No. of fish/ } \\
\text { group }\end{array}$ & $\begin{array}{c}\text { Dose } \\
(\mathrm{mg} / \mathrm{l})\end{array}$ & $\begin{array}{c}\text { No. of } \\
\text { dead fish }\end{array}$ & $\mathrm{A}$ & $\mathrm{B}$ & $(\mathrm{AxB})$ \\
\hline 1 (control) & 10 & 0 & 0 & 0 & 0 & 0 \\
2 & 10 & 10 & 0 & 0 & 0 & 0 \\
3 & 10 & 20 & 0 & 0 & 10 & 0 \\
4 & 10 & 30 & 0 & 0 & 10 & 0 \\
5 & 10 & 40 & 2 & 1 & 10 & 10 \\
6 & 10 & 50 & 4 & 3 & 10 & 30 \\
7 & 10 & 60 & 5 & 4.5 & 10 & 45 \\
8 & 10 & 70 & 7 & 6 & 10 & 60 \\
9 & 10 & 80 & 9 & 8 & 10 & 80 \\
10 & 10 & 90 & 10 & 9.5 & 10 & 95 \\
\hline 24 hours $L_{50}=$ largest dose which killed all fish- $\Sigma(\mathrm{AxB}) / \mathrm{n}$ & & & \\
24 hours $\mathrm{LC}_{50}$ of trichlorfon=90-320/10=58 mg/l & & & & \\
\hline
\end{tabular}

Regarding, the intensity in infested $C$. idella brooders was 1-10 parasite/fish.

\section{Water Quality}

In the first season of study (April to October, 2015), the temperature and $\mathrm{pH}$ of pond water during lernaeosis examination ranged from 21.66 to $32^{\circ} \mathrm{C}$ and 6.3 to 7.6 respectively. On the other hand, the temperature and $\mathrm{pH}$ of pond water throughout the second season of study (April to October, 2016) ranged from 22.57 to $29.6^{\circ} \mathrm{C}$ and 6.3 to 8.1 respectively (Table 1 ).

\section{The LC50 of Trichlorfon, Carvacrol and Cymene Mixture and Thyme}

The $\mathrm{LC}_{50}$ of trichlorfon, carvacrol and cymene mixture and thyme was $58 \mathrm{mg} / \mathrm{l}, 540 \mathrm{ul} / \mathrm{l}$ and $660 \mathrm{ul} / \mathrm{l}$ (Table 2, 3). 
Table 3. 24 hours median lethal concentration of carvacrol and cymene mixture and thyme in C. idella fingerlings

\begin{tabular}{|c|c|c|c|c|c|c|c|c|c|c|}
\hline $\begin{array}{l}\text { Group } \\
\text { Fish group } \\
\quad \text { plant extracts }\end{array}$ & $\begin{array}{l}\text { No. of fish/group } \\
\text { Carv. and } \\
\text { cym. mix. Thyme }\end{array}$ & $\begin{array}{l}\text { Dose (ul/l) } \\
\text { Carv. and } \\
\text { cym. mix. Thyme }\end{array}$ & \multicolumn{2}{|c|}{ No. of dead fish } & \multicolumn{2}{|l|}{$A$} & \multicolumn{2}{|l|}{ B } & \multicolumn{2}{|c|}{$(\mathrm{AxB})$} \\
\hline 2 & 10 & 100 & 0 & 0 & 0 & 0 & 0 & 0 & 0 & 0 \\
\hline 3 & 10 & 200 & 0 & 0 & 0 & 0 & 100 & 100 & 0 & 0 \\
\hline 5 & 10 & 400 & 2 & 1 & 1.5 & 0.5 & 100 & 100 & 150 & 50 \\
\hline 6 & 10 & 500 & 5 & 2 & 3.5 & 1.5 & 100 & 100 & 350 & 150 \\
\hline 7 & 10 & 600 & 6 & 3 & 5.5 & 2.5 & 100 & 100 & 550 & 250 \\
\hline $\begin{array}{l}24 \text { hours } L C_{50}=\text { largest do } \\
24 \text { hours } L C_{50} \text { of carvacrol } \\
24 \text { hours } L C_{50} \text { of thyme }=9\end{array}$ & $\begin{array}{l}\text { e which killed all fish- } \Sigma \text { (Ax } \\
=900-3600 / 10=540 \mathrm{ul} / \mathrm{I} \\
0-2400 / 10=660 \mathrm{ul} / \mathrm{l}\end{array}$ & $\mathrm{x} B) / \mathrm{n}$ & & & & & & & & \\
\hline
\end{tabular}

Table 4. The efficiency of trichlorfon and carvacro and cymene mixture and thyme in lernaeosis control

\begin{tabular}{|c|c|c|c|c|}
\hline Items & Trichlorfon & Carvacrol and cymene mixture & Thyme & Control \\
\hline Dose & $0.33 \mathrm{mg} / \mathrm{l}$ & $200 \mathrm{ul} / \mathrm{l}$ & $200 \mathrm{ul} / \mathrm{l}$ & 0 \\
\hline No. of fish & 12 & 12 & 12 & 12 \\
\hline Initial no. of L.cyprinacea & 59 & 70 & 62 & 64 \\
\hline No. of dropped L.cyprinacea at $7^{\text {th }}$ day post application & 44 & 42 & 26 & 4 \\
\hline$\%$ of reduction of lernaea no. at $7^{\text {th }}$ day post application & 74.5 & 60 & 41.9 & 6.2 \\
\hline \multicolumn{5}{|c|}{ The $2^{\text {nd }}$ application } \\
\hline Dose & $0.33 \mathrm{mg} / \mathrm{l}$ & $200 \mathrm{ul} / \mathrm{l}$ & $200 \mathrm{ul} / \mathrm{l}$ & 0 \\
\hline Total \% of lernaea reduction after 2 applications & 100 & 74.28 & 50.2 & 9.5 \\
\hline
\end{tabular}

\section{The efficiency of Trichlorfon, Carvacrol and Cymene Mixture} and Thyme in Lernaeosis Control

The percentage of $L$. cyprinacea reduction at $7^{\text {th }}$ day post first application of trichlorfon, carvacrol and cymene mixture and thyme was 74.5, 60 and 41.9 respectively in comparison with 6.2 reduction in control group. Regarding, the total percentage of L. cyprinacea reduction at $7^{\text {th }}$ day post second applications of trichlorfon, carvacrol and cymene mixture and thyme was 100, 74.28 and 50.2 respectively in comparison with 9.5 reduction in control group (Table 4).
Trichlorfon is an organophosphate insecticide used to control a variety of arthropod pests in agriculture and veterinary (Lopes et al., 2006). Safety of trichlorfon is questionable as it has not a restricted use in various countries including Egypt and it prohibited for food fish in others. Also, several trials in the world were conducted to find effective safe alternatives to trichlorfon for lernaeosis control. Consequently this study was planned to evaluate the safety and effectiveness of trichlorfon in lernaeosis prevention among cyprinids as they are economically important food fish under field condition. In addition, it compared with plant extracts (carvacrol and cymene mixture and thyme) as safe materials for lernaeosis control. 
To evaluate the trichlorfon safety, its bioconcentration in cyprinids fries and fingerlings and their environments (water, plants and soil) was determined after $1 \mathrm{hr}, 5$ days and 5 months from application of its field dose. Concerning the fries, post 5 days, no fish sample could be examined as they was very small in size and all environmental samples were negative. Similarly, all samples including fish that collected after 5 months were free from the trichlorfon. On the other hands on exposure of the fingerlings to the field dose, trichlorfon was detected in all samples except soil after $1 \mathrm{hr}$, but it disappeared from them including soil when tested after 5 days and 5 months. Highest trichlorfon concentration appeared in fish fingerlings (1.076 ppm) then water (0.039 ppm) and plants $(0.004$ ppm) (Figure 1). Undetection of trichlorfon in soil may be due to its high water solubility and low octanol-water partition coefficient, so, it remains in water rather than partition to organic matter (Canadian Council of Ministers of the Environment 2012). This is supported by HSDB (1999) who mentioned that trichlorfon has a low soil adsorption coefficient which indicating that it does not have an affinity for sediment or suspended solids. Additionally, trichlorfon was not detected in other samples after 5 days or 5 months may be due to its degradation into dichlorvos (Lopes et al., 2006) especially at pH levels greater than 5.5 (IPCS, 1992). Dichlorvos is the main metabolic form of trichlorfon and it does not significantly bioaccumulate in fish or other aquatic life due to its high solubility in water (Howard, 1991). Once it becomes in contact with water, hydrolysis reactions is the predominant mechanisms for degradation, and hydrolysis proceeding more rapidly with increasing $\mathrm{pH}$ and temperatures (Faust and Suffet, 1966; Lamoreaux and Newland, 1978). These findings were supported by (Lamoreaux and Newland, 1978) who confirmed that degradation of dichlorvos is due to its abiotic degradation via hydrolysis which is the major transformation process (70\%) and biodegradation by some microorganisms as Escherichia coli and Serratia plymuthica (30\%). So, dichlorvos shows little tendency to sorb to soil particles or bioconcentrate in living tissues (PIP-Dichlorvos, 1993).

Regarding the effectiveness of trichlorfon in lernaeosis prevention in hatchery reared cyprinids, it was found that prevalence of lernaeosis was low during 2 successive years. In 2015, 1 and 9 infested C. idella fingerlings and brooders respectively were recorded. In 2016, the overall prevalence among fingerlings of C. idella, H. molitrix and C. carpio was $3.33 \%, 1.57 \%$ and $1.42 \%$ respectively, while in brooders, there was only one infested $C$. idella with a prevalence of $0.19 \%$.

The intensity of infestation was still higher especially in $\mathrm{H}$. molitrix fingerlings as it reached to 19 parasite/fish our results were agreed with Abd El-Galil et al. (2012).

Lernaeosis was endemic in Egyptian hatcheries till 2014. Consequently, Hatcheries are responsible for frequent appearance of lernaeosis among cultured cyprinids in fish farms due to their role in spreading of the disease via purchase of infested fingerlings. Several studies were conducted on the prevalence of lernaeosis among hatchery reared cyprinids and proved that the prevalence till 2014 was high and reached to $72 \%$ in fingerlings and 44\% among brooders (Abd El-Rahman, 2000; Abd El-Galil, 2004; Saleh et al., 2009; Abd El-Galil et al., 2012; Korni, 2014).
These changes in lernaeosis prevalence may be due to climate changes associated with high unsuitable water temperature as it reached to $32^{\circ} \mathrm{C}$ in 2015 (Table 1), whereas, environmental temperature plays a significant role in survival and development of lernaeid copepods and water temperature of $26-27^{\circ} \mathrm{C}$ is ideal for complete the life cycle (Raissy et al., 2013; Mirzaei et al., 2014). Additionally, these prevalence variations may be due to periodic using of trichlorfon in the hatchery for prevention and control of lernaeosis. In 2016, the prevalence was relatively higher due to better climate conditions (Table 1) with suitable temperature in this year, but, the prevalence was still low in comparison with the previous years.

In this study, lernaeosis affected fish showed swollen hyperemic nodules and open wounds at the site of attachment of macroscopic lernaea parasitic females on the body and fins (Figure 2). Similar clinical abnormalities of affected cyprinids were reported by Abd El-Rahman (2000); Abd El-Galil (2002); Mancini et al. (2006); Abd El-Galil et al. (2012); Noor El-Deen et al. (2013) and Korni (2014).

Also, in this investigation the safety and effectiveness of trichlorfon in lernaeosis control in C. idella fingerlings was compared with carvacrol and cymene mixture and thyme which are the major components of thyme extract (Rattanachaikunsopon and Phumkhachorn, 2010) as safe natural by-products. First, on determination of the $\mathrm{LC}_{50}$ of trichlorfon and previous plant extract, that of the $\mathrm{LC}_{50}$ of trichlorfon was $58 \mathrm{mg} / \mathrm{l}$ (Table 2), $540 \mathrm{ul} / \mathrm{l}$ and $660 \mathrm{ul} / \mathrm{l}$ for carvacrol and cymene mixture and thyme respectively (Table 3). However, trichlorfon still safe as treatment dose is 0.33 $\mathrm{mg} / \mathrm{l}$. About their efficiency in lernaeosis control, trichlorfon succeded in complete removal of lernaea from infested C. idella fingerlings after 2 applications, whereas carvacrol and cymene mixture and thyme eliminated $74.28 \%$ and $50.2 \%$ of the lernaea respectively (Table 4). These results were supported by Korni (2014) who proved that carvacrol and cymene mixture succeeded in eliminating $88.8 \%$ of lernaea at $96 \mathrm{hrs}$ after $48 \mathrm{hrs}$ water bath treatment of C. carpio fries. Also, Troncoso et al. (2011) and Bernd et al. (2012) reported that carvacrol had a high potential to reduce sea lice infestation by bath treatment as it killed $100 \%$ of the parasite within $48 \mathrm{~h}$ of in vitro application.

\section{CONCLUSIONS}

Trichlorfon may be safe and effective in lernaeosis prevention and control. It has a low persistence in water and had no residue in fish tissues. Also, with periodic using of trichlorfon, there was only sporadic infested fish in the hatchery which has no impact on the economy. Moreover, it succeeded in elimination of $100 \%$ of $L$. cyprinaea comparing with $74.28 \%$ and $50.2 \%$ in carvacrol and cymene mixture and thyme treated fish respectively. So, trichlorfon can be used in food fish for lernaeosis prevention and control.

\section{ACKNOWLEDGMENT}

We would like to thank manager of Abo-Saleh fish hatchery, Beni-Suef, Egypt for his cooperation for fish samples collection. Also, we would like to thank Scientific Research Developing Unit, Beni-Suef University for its financial support. 


\section{REFERENCES}

Abd El-Galil, M.A.A. (2002). Studies on lernaeosis in cultured fresh water fish in in Beni-Suef governorate. Ph.D. Thesis, Fish Diseases and management. Fish Department, Faculty Veterinary Medicine, BeniSuef, Cairo University.

Abd El-Galil, M.A.A. (2004). Studies on the treatment of Lernaeosis in farmed Cyprinus carpio by Ivermectin. $11^{\text {th }}$ Scientific Cong., faculty of Veterinary Medicine. Assiut University. Egypt. p 335-350.

Abd El-Galil, Essa, M.A.A., Korni, F.M.M. (2012). Studies on lernaeosis and the efficacy of dipterex as treatment in the hatchery reared fingerlings of cyprinids. American Science Journal, 8, 574-580.

Abd El-Moula, I.H. (2001). Studies on the control of prevailing parasitic diseases among ornamental fish. MVSc. Thesis, Faculty of Veterinary Medicine, Suez Canal University.

Abd El-Rahman, M. M. (2000). Studies on cultured fish diseases induced by lernaea spp. Thesis of Ph. D. Fish Diseases and management. Fish Department, Faculty of Veterinary Medicine, Suez Canal University.

Becky, I. (2004). NWFHS Laboratory Procedures manual, 2nd Ed. chapter 8 , section general parasitology. Comstock Publishing Associates. Ithaca \& London. p 8-11.

Behrens, B. and Kerber, J. (1953). Archive of Experimental Pathology and Pharmacology. 177.

Bernd, W. B., Kjetil F., Olaug, H., Marco, A.M.M., Kjersti S.R., Carlos, A.R.V. (2012). Anti-sea lice compositions and their use. Envirom Patent Holding As. Publication number, WO2012001668.

Canadian Council of Ministers of the Environment. (2012). Canadian water quality guidelines for the protection of aquatic life: Trichlorfon. In: Canadian environmental quality guidelines, 1999, Canadian Council of Ministers of the Environment, Winnipeg.

Devine, J.M. (1973). Determination of Trichlorfon [O,O-Dimethyl (2,2,2-Trichloro-1- hydroxyethyl) phosphonate] in Forest Environmental Samples. Journal of Agricultural and Food Chemistry 21, 1095-1098. [CrossRef]

EPA, 2001. US Environmental Protection Agency. Report on FQPA Tolerance Reassessment Progress and Interim Risk Management Decision (TRED) for Trichlorfon. EPA, Washington, DC.

Fasial, M., Essa M.El.S., Shalaby, S.I., Ibrahim, M.M. (1988). Epizootic of Lernaea cyprinacea (Copepod lernaeidae in cyprinid) imported to Egypt. Egyptian Journal of Comparative Patholology and Clinical Patholology, 8, 127-148.

Faust, S.D., Suffet, I.H. (1966). Recovery, separation and identification of organic pesticides from natural and potable waters. Residues Reviews, 45-I 16. [CrossRef]

Hem, L., Sathya, K., Choi, H., Morgan, E.D. Abd El-Aty, A.M., Shim, J. (2010). Determination of Trichlorfon Pesticide Residues in Milk via Gas Chromatography with $\mu$-Electron Capture Detection and GCMS. Toxicology Research Journal, 26, 149-155. [CrossRef]

HSDB (Hazardous Substances Data Bank), (1999). Trichlorfon. National Library of Medicine, Bethesda, MD. Available from: http://toxnet.nlm.nih.gov/

IPCS (International Programme on Chemical Safety) (1992). Environmental Health Criteria No. 132. Trichlorfon. World Health Organization, Geneva.

Howard, P.H. (1991). Handbook of Environmental Fate and Exposure Data for Organic Chemicals. Lewis Publishers, 3, 251-258.

Korni, F.M.M. (2014). Lernaeosis affecting hatchery reared common carp (Cyprinus carpio) fries and a novel approach for its treatment. Global Journal of Fisheries and Aquaculture Research, 1, 173-189.

Lamoreaux, R.F., Newland, L.W. (1978). The Fate of Dichlorvos in Soil. Chemoshpere 10, 807-814. [CrossRef]

Lopes, R.B., Paraiba, L.C., Ceccarelli, P.S. Valdemar, L.T. (2006). Bioconcentration of trichlorfon insecticide in pacu (Piaractus mesopotamicus). Chemosphere, 64, 56-62. [CrossRef]
Nelson, J.S. (1994). Fishes of the World. 3rd ed. New York. John Wiley \& Sons. ISBN 0471547131.

Nelson, J.S. (2016). Fishes of the World. 4rd ed. New York. John Wiley \& Sons. ISBN 0471250317. [CrossRef]

Noga, E.J. (2010). Fish disease: Diagnosis and treatment. Copyright Mosby-year Book, Watsworth. Publishing, 2nd editor, Co., USA. [CrossRef]

Noor El-Deen, A.I.E., Azza, H.M.H., Abeer E.M. (2013). Studies on lernaeosis affecting cultured golden Fish (Carassius auratus) and trail for its treatment in earthen ponds at Kafr El-Sheikh governorate, Egypt. Global Veterinaria 11, 521-527.

Mancini, M. (2006). Main diseases of pejerrey (Odontesthes bonariensis) in central Argentina. Pesquisa Veterinária Brasileira 26, 205-210. [CrossRef]

Mirzaei, M., Khedri, J., Ghashghaei, O. (2014). Survey of Lernaeid in Shizothorax zarudnyi from Chahnimeh lakes in Sistan, Iran. Journal of Parasitiology Disease 40, 505-509. [CrossRef]

PIP-Dichlorvos (1993). Exotoxnet Profilefor dichlorvos. Extension toxicology network, pesticide information project, Cornell University, Ithaca, NY.

Raissy, M, Sohrabi, H.R., Rashedi, M., Ansari, M. (2013). Investigation of a parasitic outbreak of Lernaea cyprinacea Linnaeus (Crustacea: Copepoda) in Cyprinid fish from Choghakhor lagoon. Iranian Journal of Fisheries Sciences 12, 680-688.

Rashid, M., Balkhi, M.H., Naiko, G.A., Ahamad, T. (2014). Induced breeding of grass carp (Ctenopharyngodon idella) and silver carp (Hypophthalmichthys molitrix) using ovatide as synthetic hormone at national fish seed farm (Nfsf) manasbal, Kashmir, J\&K. Fisheries and Aquaculture Journal 5, 2-4.

Rattanachaikunsopon, P. and Phumkhachorn, P. (2010). Assessment of synergistic efficacy of carvacrol and cymene against Edwardsiella tarda in vitro and in Tilapia (Oreochromis niloticus). African Journal of Microbiology Research 4, 420-425.

Rosa, M.T., Alaíde, A.F.G., Niege, A.J.C., Furtado, P.S.C., Sérgio, A., Jairo, K.B. (2003). Activity of the Pinus elliottii resin compounds against Lernaea cyprinacea in vitro. Veterinary Parasitology, 118, 143-149. [CrossRef]

Saleh, O.A. and Abd El-Rahman, M.M. (2009). A study on prevalence and intensity of Lernaea cyprinacea infestation among carp species in Centeral Laboratory of Aquaculture Research (CLAR) hatchery, Abbassa. Abbassa International Journal For Aquaculture, ISSN 1687-7683, Special Issue for Global Fisheries and Aquaculture Research Conference, Cairo International Convention Center, $367-$ 376.

Sataporn, D. (2004). Application of Medicinal Herbs to Aquaculture in Asia. Walailak Science \& Technology Journal, 1, 7-14.

Tamuli, K.K. and Shanbhogue, S.L. (1995). Biological control of lernaea L. infection employing Oreochromis mossambica, peters. Journal of the Assam-Society, 37, 123-128.

Tamuli, K.K. and Shanbhogue, S.L. (1996). Incidence and intensity of anchor worm Lernaea bhadraensis infection on cultivated carps. Environment-and-Ecology 14, 282-288.

Troncoso, K.J., Gonzles, F.N., Pino Marambio, J.E., González, V.J., ELMowafi, A. (2011). Carvacrol and/or thymol or composition there for preventing infection infestation of an ectoparastic copepod in fish. Envirom Patent Holding As. Publication number, WO2012001668 A1.

Woo, P.T.K. (1995). Fish Diseases and Disorders Book. $2^{\text {nd }}$ ed, Vol. I, Protozoan and Metazoan infections, Phylum Arthropoda, pp. 486-494.

Xinhua, Y. (1999). Prevention and treatment of common diseases and parasites of Chinese carp. Asian-Pacific Regional Research and Training Center for Integrated Fish Farming.

Zaki, V.H. (1999). A trial for treatment of some skin parasites causing mass mortalities among Oreochromis niloticus in Manzala hatchery. BeniSuef Veterinary Medicine Journal, 3, 287-297. 